\title{
Recent outbreak of Fusarium crown and root rot caused by Fusarium solani on marjoram in Argentina
}

\author{
S. A. Gaetán ${ }^{\mathrm{A}, \mathrm{B}}$, M. S. MadiaA and A. Perez ${ }^{\mathrm{A}}$

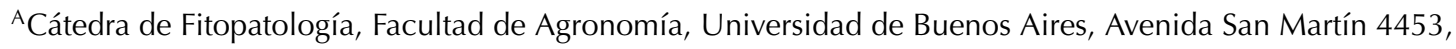 \\ CP 1417 DSE, Buenos Aires, Argentina. \\ ${ }^{B}$ Corresponding author. Email: sgaetan@agro.uba.ar
}

\begin{abstract}
In 2005, marjoram (Origanum vulgare) plants were found decayed in Cordoba Province, in Argentina. Disease symptoms included wilting, crown and root rot and plant death. Koch's postulates were fulfilled. This appears to be the first record of a recent outbreak of Fusarium crown and root rot of marjoram caused by Fusarium solani in Argentina.
\end{abstract}

Commercial production of marjoram (Origanum vulgare) (primarily processed as a dry herb) has greatly increased in Argentina and is traditionally important to the rural economy of several provinces of the western region of the country. Commercial cultivations of marjoram are largely produced in open fields in Córdoba, Mendoza, San Juan and San Luis Provinces, although some smaller cultivations have been carried out in several localities of Buenos Aires and Santa Fe Provinces.

During the last three years, a high percentage (15 to $25 \%$ ) of 8- to 12-month-old plants of marjoram have been found decayed in several fields located in Luyaba (Transierra), in the midwest region of Córdoba Province. Disease symptoms consisted of chlorosis, stunting, wilting, premature defoliation, and crown and root rotting appeared in irregular-shaped sectors of the crop spreading throughout the production area (Fig. 1). Symptoms began as foliage yellowing followed by an apical and marginal

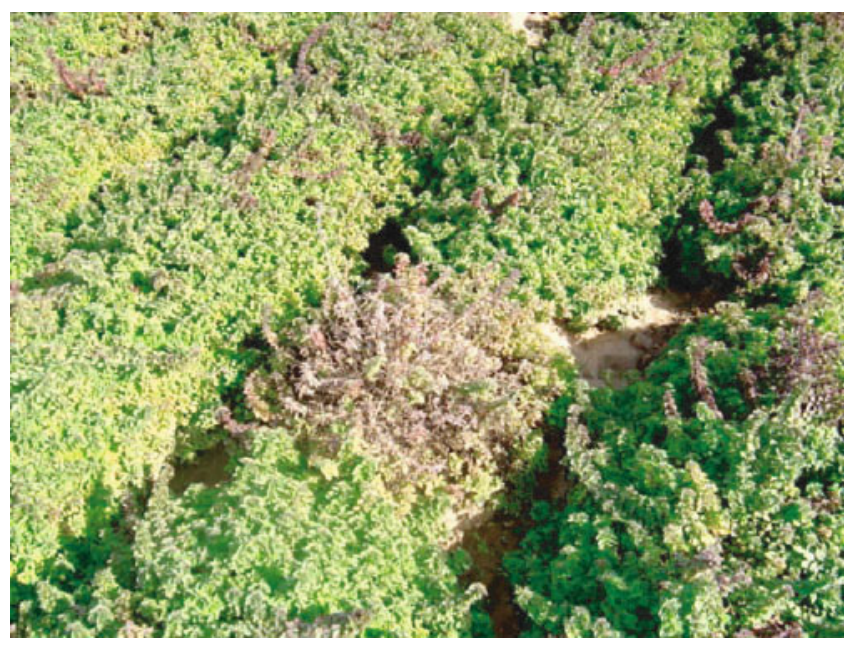

Fig. 1. Fusarium crown and root rot caused by Fusarium solani on a marjoram (Origanum vulgare) crop grown in Luyaba, in Córdoba Province, in Argentina. brown necrosis of the leaves (Fig. 2). Lesions expanded and coalesced rapidly to form large necrotic areas causing a severe defoliation beginning from the basal leaves to the upper leaves. A dry rot also developed in both crown and roots causing a complete maceration of these tissues and stunted plant growth eventually occurred. Infected plants broke off easily since the roots and the crown region were destroyed. At advanced stages of infection, a dark discoloration covering the stems developed and progressed above the soil line to the apex. Also, the crowns of affected plants were covered with masses of mycelia and conidia. The infected stems became dry and breakable (Fig. 2). Finally, the infected plants decayed, collapsed and then eventually died.

Segments (1-cm long) excised from both crowns and roots of symptomatic plants that were submitted by producers in September of 2005 were thoroughly surface sterilised with $1 \%$

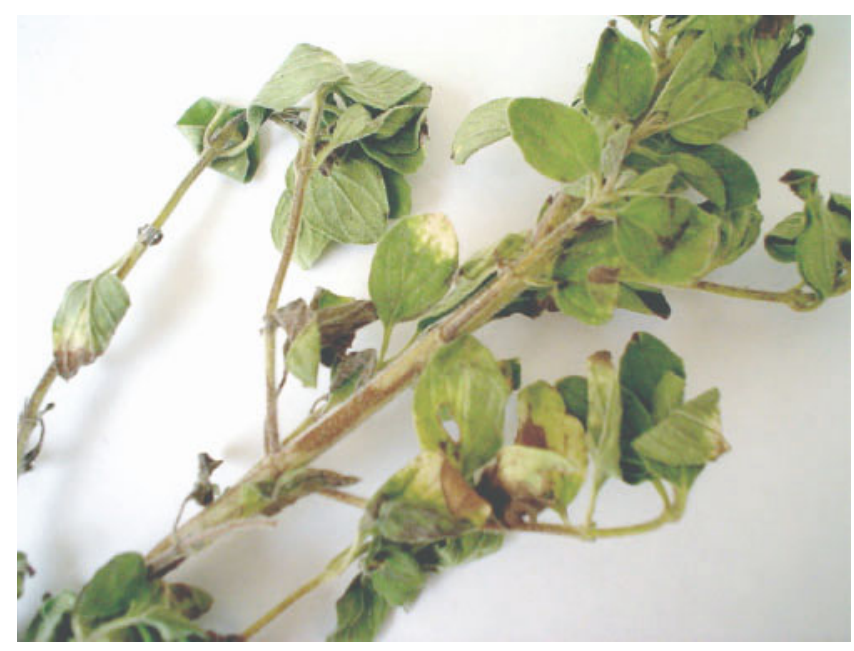

Fig. 2. Fusarium crown and root rot caused by Fusarium solani on marjoram (Origanum vulgare) leaves showing apical and marginal necrosis symptoms. 
$\mathrm{NaOCl}$ for $2 \mathrm{~min}$ and then rinsed in sterile water. Each segment was blotted dry and plated onto potato dextrose agar (PDA) medium. Plates were incubated in the dark at $26^{\circ} \mathrm{C}$ for 2 days and placed under $12 \mathrm{~h}$ of near ultraviolet light and $12 \mathrm{~h}$ dark each day for 8 days. Three fungal isolates were consistently recovered from the diseased tissues. Based on morphobiometric and cultural characteristics, the predominant fungus isolated was identified as Fusarium solani (Mart.) Sacc. (Booth 1971; Nelson et al. 1983). Colonies were first yellowish to cream in colour and then turned dark ochraceous. Macroconidia were abundant, 4 to 6 celled, curved, hyaline, and measured 4.5-5 × 26-39 $\mu \mathrm{m}$. Chlamydospores were also abundant and globose, whereas microconidia were rare. The teleomorph Nectria haematococca Berk. \& Broome was not observed on infected plants.

Koch's postulates were completed for three fungal isolates by dipping the roots of 3-month-old marjoram seedlings into a conidial suspension $\left(2 \times 10^{6}\right.$ conidia $\left./ \mathrm{mL}\right)$ derived from a singlespore isolate for $30 \mathrm{~min}$. Plants were repotted (five inoculated and three controls plants) in a sterilised soil mix (soil/sand, $2: 1$ ) and held in the greenhouse at $23-26^{\circ} \mathrm{C}$ with $75 \%$ relative humidity with no supplemental light. Within two weeks after inoculation, characteristic symptoms similar to the original observations at the field developed on $90 \%$ of the inoculated plants. Symptoms included chlorosis followed by wilting of the leaves, crown and root rotting and death of plants. The fungus was successfully reisolated from the symptomatic plants fulfilling Koch's postulates in all instances. Symptoms did not develop and the pathogen was not reisolated from control plants dipped only into distilled water. The experiment was performed twice and the results of the second one were identical to the first.

In 1994, the pathogen had been previously reported in Argentina on $O$. vulgare crops located at Tunuyán and San Carlos, in Mendoza Province, although the disease incidence was low (Garbagnoli and Gaetán 1994). Nevertheless, the pathogen represents a threat to commercial cultivations of marjoram in the region since mortality of plants was significantly higher in 2005 than in previous years. At the present time, further information regarding this pathogen within the region is needed.

This is the first record of a recent outbreak of Fusarium crown and root rot caused by $F$. solani on commercial crops of $O$. vulgare in Argentina.

\section{References}

Booth C (1971) 'The Genus Fusarium.' (The Eastern Press: London) Garbagnoli C, Gaetán SA (1994) Marchitamiento del orégano (Origanum vulgare L.) causado por especies del genero Fusarium en la Republica Argentina. Fitopatología 29, 150-155.

Nelson PE, Toussoun TA, Marasas WFO (1983) 'Fusarium species: an Illustrated Manual for Identification.' (Pennsylvania State University Press: University Park)

Manuscript received 7 March 2006, accepted 18 December 2006 